\title{
The influence of the profile-dividing grinding strategy on the surface accuracy and roughness of a gear teeth
}

\author{
Wpływ strategii szlifowania kształtowo-podziałowego \\ na dokładność i chropowatość uzębień kół zębatych
}

\section{PIOTR ZYZAK \\ PAWEK KOBIELA \\ ARNOLD BROŻEK MAREK GABRYŚ *}

In the paper are presented investigation results of an effects of adopted strategy of profile-dividing grinding of a cylindrical gear teeth, performed on the Rapid Höfler 900 grinder, on machining accuracy and surface roughness of the teeth. The strategies have taken into considerations changes in the following parameters determining obtained results of the grinding: number of passes, number of leads, shaping method of the grinding wheel.

KEYWORDS: tooth gears, profile dividing grinding, results of the grinding operation

Profile grinding relies on the machining of the working surfaces of the wheel teeth using a grinding wheel appropriately shaped to the shape of a tooth profile. It is extremely important to accurately make such grinding wheel and to control the level of its wear, because it determines the final geometry of the sprocket. In the case of this type of finishing treatment, intensive cooling is necessary. The main advantage of this method is the linear contact of the grinding wheel outline with the profile of the shaped teeth, which allows to achieve high machining efficiency. Grinding has a direct effect on the operational properties of the toothed wheel [11].

Considering the fact that finishing treatment with grinding is long-lasting, and thus expensive, one should strive to achieve a certain class of accuracy of gears already during machining [3]. Profile-dividing grinding is the most accurate method of gear finishing machining, especially with unsymmetrical grinding, due to the more favorable working conditions of the tool $[1-3,9]$.

There are three methods of profile grinding [3]:

- with symmetrical position of a grinding wheel - the advantage of this method is that two sides of adjacent teeth are ground at the same time; working conditions of the grinding wheel, resulting from the variable grinding depth along the profile of the grinding wheel during radial feed, can be regarded as a disadvantage;

- with asymmetrical position using one grinding wheel the advantage of this method is more favorable grinding wheel working conditions, where only one side of the tooth is machined;

\footnotetext{
* Dr inż. Piotr Zyzak (pzyzak@ath.bielsko.pl) - Akademia Technicz no-Humanistyczna w Bielsku-Białej; mgr inż. Paweł Kobiela (pawel. kobiela@befared.pl), inż. Arnold Brożek (arnoldbrozek@gmail.com), mgrinż. Marek Gabryś (marek.gabrys@befared.pl)-Fabryka Reduktorów i Motoreduktorów BEFARED Spółka Akcyjna
}

- with asymmetrical position of two grinding wheels - the advantage of this method is favorable grinding wheel operating conditions, and the disadvantage - the necessity of using two grinding wheels.

It is assumed that the undoubted advantages of the profiling methods are: possibility of giving the outline of teeth of any shape and the possibility of grinding teeth in wheels with internal toothing $[7,9]$.

\section{Test stand - Rapid Höfler 900 grinder}

The Rapid Höfler 900 grinder for profile grinding of gears is installed at BEFARED, a company dealing in the production of general purpose gear reducers and motoreducers. Fig. 1 shows the axes of the machine tool and the process of dressing the grinding wheel with a circular diamond shredder.

In the Rapid Höfler 900 grinder, axes are assigned to the main sub-assemblies (performing specific functions), such as $[7,8]$ :

- grinding head ( $A$ axis) - deflection of the grinding wheel to the inclination angle,

- table of workpieces ( $B$ axis) - graduation,

- grinding spindle ( $C$ axis) - rotational motion of the grinding spindle during grinding,

- dressing spindle (C2 axis) - rotation of the dressing roller during dressing,

- slide of workpieces ( $X$ axis) - setting the diameter,

- tool carriage ( $Y$ axis) - step motion,

- dressing sleeves (Z2 axis) - creating a tool profile.
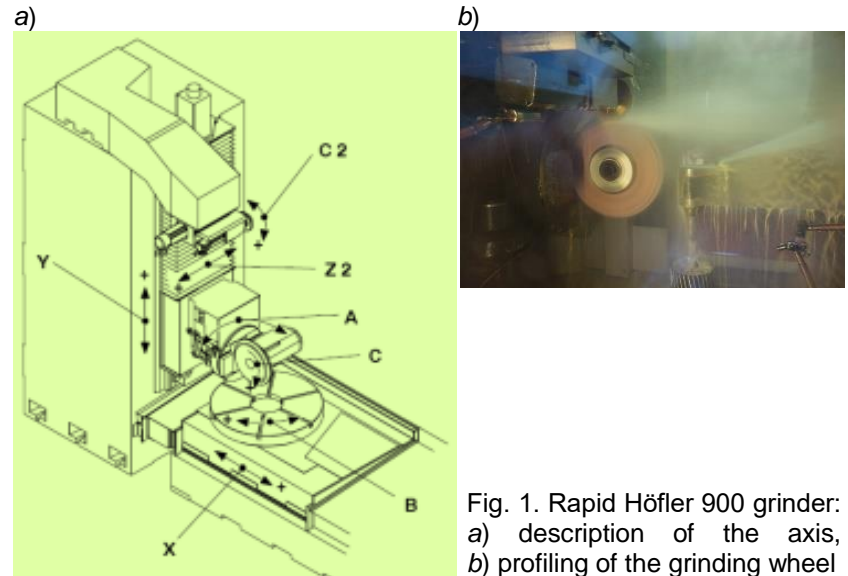

Fig. 1. Rapid Höfler 900 grinder: a) description of the axis, b) profiling of the grinding wheel 


\section{Course of profile-dividing grinding for selected gear wheels}

The main parameters of grinding gears are:

- number of jumps - this is the number of passes of the grinding wheel in a single tooth space;

- number of passes - one pass corresponds to grinding all teeth in one series, e.g. six jumps per tooth space;

- circular grinding wheel speed, rev/min;

- drive power of the grinding wheel, $W$;

- depth of grinding/cutting (depending on the amount of finishing allowance), $\mathrm{mm}$;

- criteria for dressing the grinding wheel: type of movement of the dressing roller relative to the grinding wheel (corotating or counter-rotating); rotation speed of the grinding wheel, revolutions per minute; rotational speed of the dressing roller, rev/min; the number of dressing processes; radial dressing delivery, $\mathrm{mm}$; ratio of the speed of dressing; number of dressing processes after re-profiling.

During the own tests, the following parameters of the profile-dividing grinding were changed in the program of machining of gears: the number of passes, number of jumps, shaping the profile of the grinding wheel. On the basis of the grinding analysis of gear wheels in industrial conditions, it was found that more passes than jumps should be made, because a higher number of jumps can lead to weakening of the tooth base.

In the profile-division grinding, the tool, i.e. the grinding wheel, including the material from which it was made, and the manner in which it was dressed (method of preparing the active surface of the grinding wheel) have a decisive influence on the quality of the treated surface.

The grinding operation on the Rapid 900 grinder from Höfler was applied to two gears made of C55 steel (with the following elements contents: $0.52 \div 0.6 \% \mathrm{C}, 0.6 \div 0.9 \% \mathrm{Mn}$, $\max .0 .4 \% \mathrm{Si}$, max. $0.045 \% \mathrm{P}$, max. $0.045 \% \mathrm{~S}$, $\max .0 .4 \%$ $\mathrm{Cr}$, max. $0.4 \% \mathrm{Ni}$, max. $0.1 \% \mathrm{Mo}$ ) after induction hardening. The wheel characteristics were as follows:

- module $m=5 \mathrm{~mm}$,

- number of teeth with $=31$,

- pitch diameter $d_{p}=157.339 \mathrm{~mm}$,

- support angle $\alpha=20^{\circ}$,

- tooth inclination angle $\beta=9^{\circ} 53^{\prime} 30^{\prime \prime}$,

- correction factor $x=0$.

For the gears after grinding, measurements of the following deviations were made on a coordinate measuring machine: $F_{\alpha}, f_{\mathrm{f \alpha}}, f_{\mathrm{H \alpha}}, F_{\beta}, f_{\mathrm{f} \beta}, f_{\mathrm{H} \beta}, F_{\mathrm{p}}, F_{\mathrm{r}}[4-6]$.

The teeth were milled using the envelope method on the SAMPUTENSILI S800 milling machine with the SINUMERIK control system. After hobbing and deburring of the gear teeth, they were subjected to heat treatment (induction hardening by tooth-to-tooth method to obtain a hardness of $54 \div 58$ HRC).

Induction hardening of individual teeth was carried out using the feed method, where the operation is divided into one tooth during the operation. HF $35 \mathrm{~kW}$ generator and IV 630 feeder were used at $300 \div 400 \mathrm{kHz}$ frequency and $670 \mathrm{~A}$ current, machine feed 2 and hardened layer thickness about $1 \mathrm{~mm}$. After induction hardening, the wheels were subjected to a tempering operation. Fig. 2 presents the implementation of the induction hardening operation.

Based on the diameter of tooth tips (external toothing), a hole $\varnothing 90 \mathrm{H} 7 \times 80$ was ground and the surface perpendicular to it (frontal), and then the toothed wheel was fixed on a ground hole and front surface using an expansion sleeve and the teeth were ground.

At the first stage of the profile-dividing grinding of the selected toothed wheels, the coaxiality of the toothed wheel with the table axis was determined and the radial runout was checked using the Mitutoyo RRY 483 sensor (fig. 3). The radial runout value of $2 \mu \mathrm{m}(0.002 \mathrm{~mm})$ was obtained. The height of the fixing was determined and the grinding program was prepared. Then the $W_{\mathrm{k}}$ indicator (length by $k$ of teeth) was determined, which was the basis for the development of the machining task. Fastening and positioning of the gear wheel to the machine axis completes the grinding preparation stage.

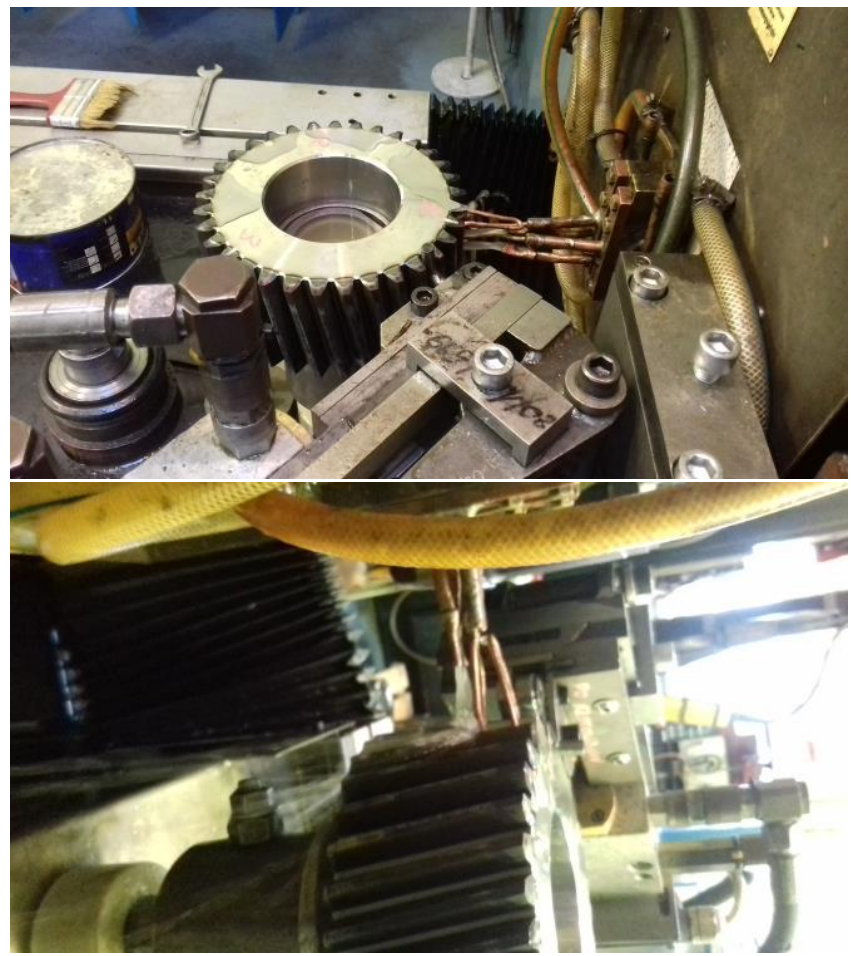

Fig. 2. Operation of induction hardening of gear wheels in industria conditions

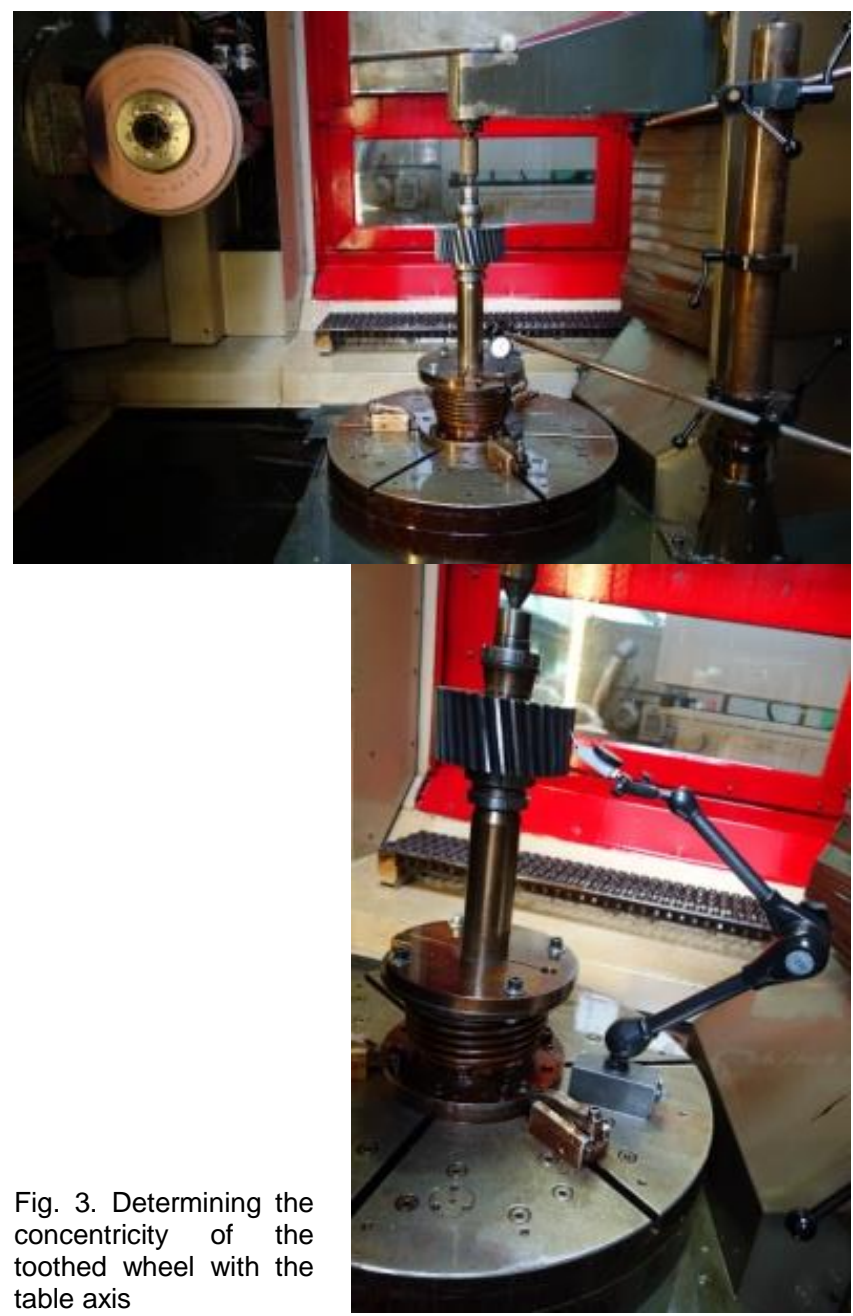


For grinding, a $3 \mathrm{M}$ grinding wheel made of electrocorundum with the designation: 22VDT1ESP400 $\times 45 \times$ 127V50U1255NA80F15VPH902W was used. Rotel Spezial 277-4 oil with an output of $150 \mathrm{l} / \mathrm{min}$ was used as a coolant.

The grinding strategy adopted for both gears (doubleface grinding) was the same - with the difference that the second wheel was immediately ground (without coarse grinding) with a coarsely stuck sharp grinding wheel which had different degree of overlap during dressing. The surface of the grinding wheel for grinding the wheel marked with the number 2 was definitely more rough - the notion of a sharp grinding wheel was introduced. In order to determine the influence of selected parameters of the profile-dividing grinding on the accuracy and roughness of grinded teeth, a different number of passes and jumps of the grinding whee were adopted (tabs. I-IV).

Implementation of the grinding operation of the selected gears required the acceptance in the program: radial dressing, $k_{d}$ coverage index [10], wheel dressing parameter $\eta$ ( $\eta$ is the ratio of peripheral speed of the dressing roller to the peripheral speed of the grinding wheel).

In roughing and finishing of wheel 1, we adopted:

- transition 1. - radial dressing delivery $0.05 \mathrm{~mm}$, coverage ratio $k_{d}=2, \eta=0.8$

- transition 2. - radial dressing delivery $0.05 \mathrm{~mm}$, coverage ratio $k_{d}=2, \eta=0.8$

- transition 3. - radial dressing delivery $0.05 \mathrm{~mm}$, coverage ratio $k_{d}=3, \eta=0.6$;

- transition 4. - radial dressing delivery $0.05 \mathrm{~mm}$, coverage ratio $k_{d}=6, \eta=-0.6$.

TABLE I. List of the types of machining carried out and the number of passes and jumps

\begin{tabular}{|l|l|l|l|l|l|l|l|l|l|l|l|l|}
\hline Gear & \multicolumn{9}{|c|}{1} & \multicolumn{4}{c|}{ Finishing } & \multicolumn{5}{c|}{2} \\
\hline Machining & \multicolumn{4}{|c|}{ Rough } \\
\hline $\begin{array}{l}\text { Number of } \\
\text { transitions }\end{array}$ & 1 & 2 & 3 & 4 & 1 & 2 & 3 & 4 & 1 & 2 & 3 & 4 \\
\hline $\begin{array}{l}\text { Number of } \\
\text { jumps }\end{array}$ & 6 & 6 & 6 & 2 & 6 & 4 & 4 & 2 & 6 & 6 & 6 & 4 \\
\hline
\end{tabular}

TABLE II. Roughing parameters - gear 1

\begin{tabular}{|c|c|c|c|c|c|}
\hline \multicolumn{2}{|c|}{ Transitions Jumps } & $\begin{array}{c}\text { Position, } \\
\mathrm{mm}\end{array}$ & $\begin{array}{c}\text { Axial } \\
\text { position, } \mathrm{mm}\end{array}$ & $\begin{array}{c}\text { Feedrate, } \\
\mathrm{mm} / \mathrm{min}\end{array}$ & $\begin{array}{c}Q_{\mathrm{w}}^{\prime}, \\
\mathrm{mm}^{3} /(\mathrm{mm} \cdot \mathrm{s})\end{array}$ \\
\hline $1 ., 2$. & $1 \div 6$ & 0.020 & 0.052 & 6000 & 5.1544 \\
\hline \multirow{2}{*}{3.} & $1 \div 4$ & 0.015 & 0.039 & 5000 & 3.2215 \\
\cline { 2 - 6 } & $5 \div 6$ & 0.010 & 0.026 & 5000 & 2.1477 \\
\hline \multirow{2}{*}{4.} & 1 & 0.010 & 0.026 & 2200 & 0.9450 \\
\cline { 2 - 6 } & 2 & 0.010 & 0.026 & 1800 & 0.7732 \\
\hline
\end{tabular}

\section{TABLE III. Finishing parameters - gear 1}

TABLE III. Finishing parameters - gear 1
\begin{tabular}{|c|c|c|c|c|c|}
\hline \multicolumn{2}{|c|}{ Transitions Jumps } & $\begin{array}{c}\text { Position, } \\
\mathrm{mm}\end{array}$ & $\begin{array}{c}\text { Axial } \\
\text { position, } \mathrm{mm}\end{array}$ & $\begin{array}{c}\text { Feedrate, } \\
\mathrm{mm} / \mathrm{min}\end{array}$ & $\begin{array}{c}Q_{\mathrm{w}}^{\prime} \\
\mathrm{mm}^{3} /(\mathrm{mm} \cdot \mathrm{s})\end{array}$ \\
\hline 1. & $1 \div 6$ & 0.020 & 0.051 & 6000 & 5.1371 \\
\hline 2. & $1 \div 4$ & 0.020 & 0.051 & 6000 & 5.1371 \\
\hline \multirow{2}{*}{3.} & $1 \div 2$ & 0.015 & 0.039 & 5000 & 3.2107 \\
\cline { 2 - 6 } & $3 \div 4$ & 0.010 & 0.026 & 5000 & 2.1404 \\
\hline \multirow{2}{*}{4.} & 1 & 0.010 & 0.026 & 2200 & 0.9418 \\
\cline { 2 - 6 } & 2 & 0.010 & 0.026 & 1800 & 0.7706 \\
\hline
\end{tabular}

TABLE IV. Machining parameters - gear 2

\begin{tabular}{|c|c|c|c|c|c|}
\hline Transitions Jumps & $\begin{array}{c}\text { Position, } \\
\mathrm{mm}\end{array}$ & $\begin{array}{c}\text { Axial } \\
\text { position, } \mathrm{mm}\end{array}$ & $\begin{array}{c}\text { Feedrate, } \\
\mathrm{mm} / \mathrm{min}\end{array}$ & $\begin{array}{c}Q_{\mathrm{w}}^{\prime} \\
\mathrm{mm}^{3} /(\mathrm{mm} \cdot \mathrm{s})\end{array}$ \\
\hline $1 ., 2 ., 3$. & $1 \div 6$ & 0.020 & 0.051 & 6000 & 5.1371 \\
\hline 4. & $1 \div 4$ & 0.020 & 0.051 & 6000 & 5.1371 \\
\hline
\end{tabular}
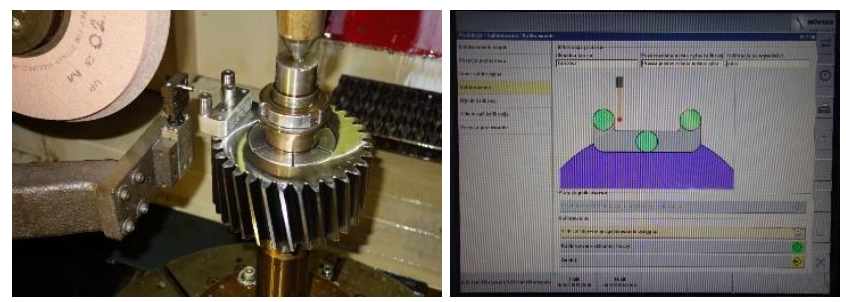

Fig. 4. Calibration of the lower external measuring arm on the Rapid Höfler 900 grinder
In the case of machining the wheel 2 in transitions $1 \div 4$ there were assumed: radial delivery of dressing $0.05 \mathrm{~mm}$, coverage ratio $k_{d}=2, \eta=0.8$.

In addition, the machining plan assumes that the grinding wheel is to be coarsely coated at the counter-rotating roller and grinding wheel.

After finishing the first wheel grinding, a calibration was carried out to prepare and carry out the post-grinding measurements (fig. 4). Due to the calibration, the exact position of the sensor is obtained.

\section{Results of research and discussion of results}

Based on the developed strategies, grinding of gear wheels was carried out. After the milling, induction hardening and grinding operations, the accuracy of the teeth was measured on the ZEISS PRISMO NAVIGATOR coordinate machine by Carl Zeiss and with the Vast Gold scanning head; ZEISS GEAR PRO Involute 2014 software was used. To assess the accuracy of the teeth, it was assumed (according to PN-ISO 1328-1):

- total deviation of the $F_{\alpha}$ profile,

- deviation of the $f_{\mathrm{H \alpha}}$ outline,

- shape deviation $f_{\mathrm{fa}}$,

- total deviation of the $F_{\beta}$ tooth line,

- tooth position deviation $f_{\mathrm{H} \beta}$,

- tooth shape deviation $f_{f \beta}$,

- total deviation of the $F_{\mathrm{p}}$ wheel pitch,

- pitch deviation $f_{\mathrm{p}}$

- radial runout $B_{\mathrm{r}}$.

Fig. 5 presents values of measured deviations characterizing the toothed wheels ground with the shapedividing method. Examples of graphical profile presentations for ground gears are shown in fig. 6 .

a)

\begin{tabular}{|c|c|c|c|c|c|c|c|c|c|c|c|c|c|c|}
\hline \multirow[b]{2}{*}{ Deviation } & \multirow[b]{2}{*}{$Q_{n}$} & \multirow[b]{2}{*}{ (...) } & \multicolumn{3}{|c|}{ Left side } & \multirow[b]{2}{*}{$Q_{3}$} & \multirow[b]{2}{*}{0} & \multirow[b]{2}{*}{0} & \multirow[b]{2}{*}{$Q_{3}$} & \multicolumn{3}{|c|}{ Right side } & \multirow[b]{2}{*}{$Q_{n}$} & \multirow[b]{2}{*}{ (..) } \\
\hline & & & 21 & 11 & 1 & & & & & 1 & 11 & 21 & & \\
\hline$F_{0, \mu \mathrm{m}}$ & 7 & 18 & 5 & 6 & 5 & 4 & 5 & 2 & 2 & 2 & 3 & 2 & 7 & 18 \\
\hline$f_{t}, \mu \mathrm{m}$ & 7 & 14 & 5 & 5 & 5 & 5 & 5 & 2 & 2 & 2 & 2 & 2 & 7 & 14 \\
\hline$f_{\text {tso }} \mu \mathrm{m}$ & 7 & \pm 10 & 1 & 1 & 0 & 1 & 0 & 0 & 1 & 0 & 1 & 0 & 7 & \pm 10 \\
\hline$F_{\beta}, \mu \mathrm{m}$ & 7 & 18 & 2 & 6 & 9 & 5 & 6 & 5 & 4 & 6 & 5 & 5 & 7 & 18 \\
\hline$f_{\text {s. }} \mu \mathrm{m}$ & 7 & 12 & 4 & 2 & 3 & 2 & 3 & 5 & 4 & 4 & 5 & 5 & 7 & 12 \\
\hline$f_{n g}, \mu \mathrm{m}$ & 7 & \pm 14 & 1 & 6 & 9 & 6 & 6 & 1 & 5 & 6 & 0 & -1 & 7 & \pm 14 \\
\hline
\end{tabular}

b)

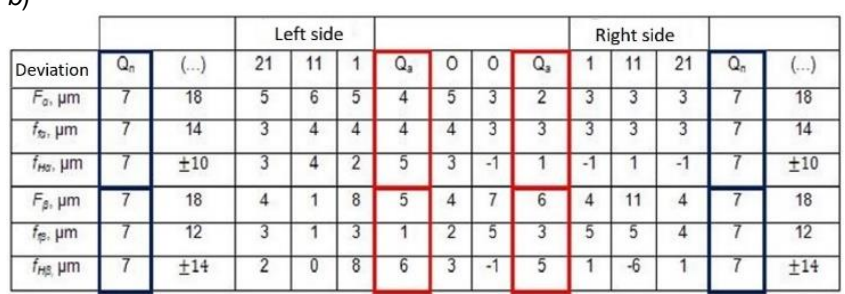

Fig. 5. Measured deviations: a) toothed wheel $1, b$ ) toothed wheel 2

a)

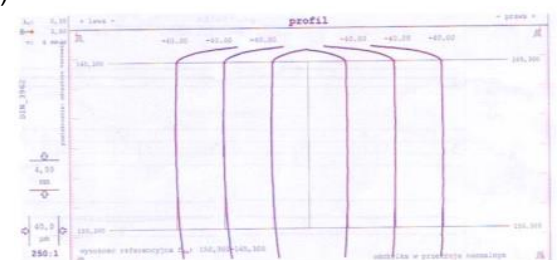

b)

Fig. 6. Graphic presentation of the profile of polished gears: a) wheel 1

b) wheel 2

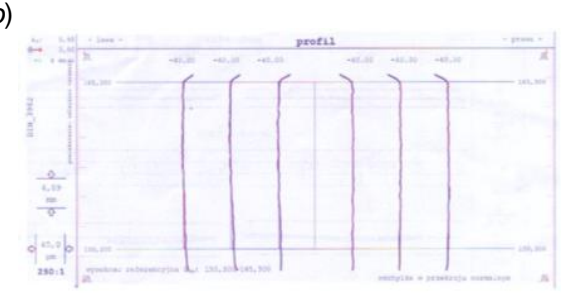




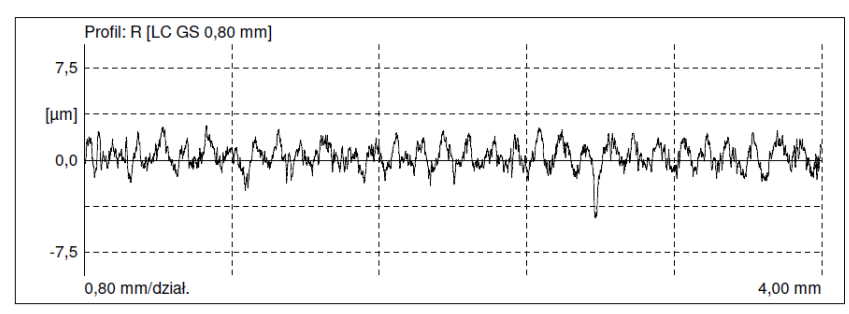

$\mathrm{Ra}$

$\begin{array}{ll}0,80 & \mu \mathrm{m} \\ 7,51 & \mu \mathrm{m}\end{array}$

Fig. 7. Surface roughness profile $R a$ (gear 2, tooth space 1, right side)

According to the construction documentation, the required tooth roughness could not exceed $R a=0.63 \mu \mathrm{m}$. The average arithmetic deviation of the roughness profile from the mean line for the toothed wheel 1 and the toothed wheel 2 was measured with the elementary section length being set to $I_{r}=0.8$ for five sections $[12,13]$. The MAHR PERTHOMETER CONCEPT profilometer with the MAHR MFW-250 measuring head 6851801 and the PERTHOMETER CONCEPT V.6.50 software were used for the measurements. Both in the case of the evaluation of the accuracy of the toothing and the surface roughness assessment, measurements for the left and right sides of the 1st, 11th and 21st tooth spaces were assumed for both gear wheels. The selected profile of the surface roughness of the right side of the 1st tooth space ground with a sharp grinding wheel, is shown in fig. 7 .

The average value of the measured parameter $R a$ was respectively:

- gear 1: tooth space 1 - left side $R a=0.35 \mu \mathrm{m}$, right side $R a=0.34 \mu \mathrm{m}$; tooth space 11 - left side $R a=0.34 \mu \mathrm{m}$, right side $R a=0.37 \mu \mathrm{m}$; tooth space 21 - left side $R a=$ $0.37 \mu \mathrm{m}$, right side $R a=0.40 \mu \mathrm{m}$;

- gear 2: tooth space 1 - left side $R a=0,6 \mu \mathrm{m}$, right side $R a=0,8 \mu \mathrm{m}$; tooth space 11 - left side $R a=0.52 \mu \mathrm{m}$, right side $R a=0.69 \mu \mathrm{m}$; tooth space 21 - left side $R a=0.59$ $\mu \mathrm{m}$, right side $R a=0.7 \mu \mathrm{m}$.

Both strategies of grinding gears allowed to obtain the 6th class of the accuracy of the toothing. The deviation values characterizing the ground toothing obtained as part of the grinding strategies adopted corresponded to the required accuracy class.

The grinding strategy, including coarse and finishing grinding (gear 1), made it possible to obtain a smooth tooth surface without any visible traces of unevenness.

\section{Conclusions}

The work assumes that grinding of gear teeth will be carried out according to two strategies differing above all with the value of the coefficient $k_{\mathrm{d}}$. Allowances for grinding should be removed with proper division - so that the requirements for geometry and roughness of meshes are met, in accordance with PN ISO 1328. It was assumed to obtain 7th class of teeth precision, and as a result, the class 6 was obtained. The assessment of the indicator, which is the length through the teeth $W_{k}$ was also included. This ratio determined from measurements at the Rapid Höfler 900 grinder for both accepted grinding strategies was respectively $W_{\mathrm{k}(1)}=53.791 \mathrm{~mm}$ and $W_{\mathrm{k}(2)}=53.773 \mathrm{~mm}$ (at a set value of $W_{\mathrm{k}}=53.790 \mathrm{~mm}$ ). Teeth ground with a sharp, coarsely covered wheel was characterized by poorer surface roughness and did not meet the requirements for the average arithmetic deviation of the roughness profile $R a$.

In addition, duration of the teeth grinding operation was determined. This parameter consists of: the duration of the setting operations, implementation of the grinding operation and the measurement. For the grinding strategy adopted, these times are respectively: $t_{(1)}=110 \mathrm{~min}, t_{(2)}=50 \mathrm{~min}$.
It can be assumed that the development of an appropriate grinding strategy - taking into account the specific task, geometry of the teeth, type of treatment preceding grinding and the method of fixing and mounting the workpiece - as well as defining the grinding wheel strategy will translate into the accuracy of ground teeth.

After analyzing the state of knowledge about the grinding of teeth, it can be concluded that the profile-dividing grinding will continue to be the leading finishing treatment of the gear teeth.

\section{REFERENCES}

1. Oczoś K.E, Porzycki J. „Szlifowanie. Podstawy i technika”. Warszawa: Wydawnictwa Naukowo-Techniczne, 1986.

2. Ochęduszko K. "Koła zębate. T. II. Wykonanie i montaż”. Warszawa: Wydawnictwa Naukowo-Techniczne, 1992.

3. Oczoś K.E., Marciniak M. „Rozwój konstrukcji obrabiarek do realizacji procesów szlifowania. Część 2". Mechanik. 79, 3 (2006): pp. 192-198.

4. PN-ISO 1328-1 (1997): Przekładnie zębate walcowe. Dokładność wykonania według ISO. Definicje i wartości odchyłek jednoimiennych boków zębów.

5. PN-ISO 1328-2 (1997): Definicje i wartości odchyłek pomiarowych złożonych i odchyłek bicia.

6. DIN 3962 (1978): Toleranze für Stirnradverzahnungen. Toleranze für abweichungen einzelner Bestimmungsgrößen.

7. Instrukcja obsługi szlifierki kształtowo-podziałowej Rapid 2000 do obróbki wykańczającej uzębień firmy Höfler (Niemcy).

8. www.klingelnberg.com/en/businessdivisions/hoefler/cylindrical-gear-grinding-machines/detailpage/product/rapid-900/ (10.02.2018).

9. Płonka S., Szadkowski J., Matuszek J., Kobiela P. „Rozwój wybranych metod kształtowania obróbką skrawaniem uzębień kół zębatych". Zeszyty Naukowe Politechniki Śląskiej. Seria: Transport. 87, 1929 (2015): pp. 11-20.

10. Rosik R., Świerczyński J. „Wpływ metody MQL na parametry kształtowania czynnej powierzchni ściernicy i chropowatość warstwy wierzchniej przedmiotu obrabianego". Inżynieria Maszyn. 16, 1-2 (2011): pp. 175-185.

11. Gawroński Z. „Technologiczna warstwa wierzchnia w kołach zębatych i mechanizmach krzywkowych". Politechnika Łódzka, 2005.

12. PN-ISO 4288:1997 Długość odcinka elementarnego Ir w zależności od wartości parametrów Ra, Rz, Rsm chropowatości powierzchni.

13. PN-ISO 3274:1997 Zależności między filtrem chropowatości $\lambda c$ i $\lambda s$, promieniem wierzchołka $r_{\text {tip }}$ oraz odległością próbkowania.
Translation of scientific articles, their computer composition and publishing them on the website www.mechanik.media.pl by original articles in Polish is a task financed from the funds of the Ministry of Science and Higher Education designated for dissemination of science.

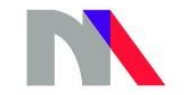

Ministry of Science and Higher Education Republic of Poland 